Meta

Journal des traducteurs

Translators' Journal

\title{
BBC English with an Accent: "African” and "Asian” Accents and the Translation of Culture in British Broadcasting
}

\section{Kenn Nakata Steffensen}

Volume 57, numéro 2, juin 2012

La manipulation de la traduction audiovisuelle

The Manipulation of Audiovisual Translation

URI : https://id.erudit.org/iderudit/1013959ar

DOI : https://doi.org/10.7202/1013959ar

Aller au sommaire du numéro

Éditeur(s)

Les Presses de l’Université de Montréal

ISSN

0026-0452 (imprimé)

1492-1421 (numérique)

Découvrir la revue

Citer cet article

Steffensen, K. N. (2012). BBC English with an Accent: "African” and "Asian" Accents and the Translation of Culture in British Broadcasting. Meta, 57(2), 510-527. https://doi.org/10.7202/1013959ar
Résumé de l'article

Les accents étrangers joués par les acteurs anglophones constituent une caractéristique omniprésente, mais politiquement et théoriquement problématique dans beaucoup de productions audiovisuelles du monde anglophone. Le présent article cherche à étudier le déploiement des accents tswana et japonais dans deux productions de la BBC en tant qu'actes de traduction audiovisuelle (TAV) illustrant une problématique générale de la représentation occidentale des langues et des cultures non-occidentales. L'article soutient que les éléments phonologiques qui sont classifiés comme des accents divisent la communauté des locuteurs natifs en différents groupes sociaux et qu'ils créent et maintiennent des frontières entre locuteurs natifs et locuteurs non natifs. La BBC reconnaît la discrimination linguistique comme un problème par rapport à son public national et l'organisme cherche activement à devenir plus inclusif et plus représentatif de la société britannique par la diffusion des accents non standards. Par contre, lorsque la $\mathrm{BBC}$ présente des langues et des cultures étrangères, surtout postcoloniales et non occidentales, l'accent est utilisé pour définir la frontière entre la communauté anglophone native et l'extérieur. Les accents sont utilisés pour représenter et traduire l'extérieur selon des stéréotypes qui tendent vers la racialisation et donc l'adoption, par les acteurs, d'accents génériques dits « de l'Afrique australe » ou " d'Asie orientale " présentant peu de ressemblance avec le profil phonologique réel des locuteurs natifs du tswana ou du japonais.
Ce document est protégé par la loi sur le droit d'auteur. L'utilisation des services d'Érudit (y compris la reproduction) est assujettie à sa politique d'utilisation que vous pouvez consulter en ligne.

https://apropos.erudit.org/fr/usagers/politique-dutilisation/ 


\title{
BBC English with an Accent: "African" and "Asian" Accents and the Translation of Culture in British Broadcasting
}

\author{
KENN NAKATA STEFFENSEN \\ University College Cork, Cork, Ireland \\ k.steffensen@umail.ucc.ie
}

\begin{abstract}
RÉSUMÉ
Les accents étrangers joués par les acteurs anglophones constituent une caractéristique omniprésente, mais politiquement et théoriquement problématique dans beaucoup de productions audiovisuelles du monde anglophone. Le présent article cherche à étudier le déploiement des accents tswana et japonais dans deux productions de la BBC en tant qu'actes de traduction audiovisuelle (TAV) illustrant une problématique générale de la représentation occidentale des langues et des cultures non-occidentales. L'article soutient que les éléments phonologiques qui sont classifiés comme des accents divisent la communauté des locuteurs natifs en différents groupes sociaux et qu'ils créent et maintiennent des frontières entre locuteurs natifs et locuteurs non natifs. La BBC reconnaît la discrimination linguistique comme un problème par rapport à son public national et l'organisme cherche activement à devenir plus inclusif et plus représentatif de la société britannique par la diffusion des accents non standards. Par contre, lorsque la BBC présente des langues et des cultures étrangères, surtout postcoloniales et non occidentales, l'accent est utilisé pour définir la frontière entre la communauté anglophone native et l'extérieur. Les accents sont utilisés pour représenter et traduire l'extérieur selon des stéréotypes qui tendent vers la racialisation et donc l'adoption, par les acteurs, d'accents génériques dits «de l'Afrique australe » ou «d'Asie orientale» présentant peu de ressemblance avec le profil phonologique réel des locuteurs natifs du tswana ou du japonais.
\end{abstract}

\begin{abstract}
Foreign accents acted by Anglophone actors are a ubiquitous but politically and theoretically problematic feature of many audiovisual productions in the English-speaking world. This paper investigates the use of Tswana and Japanese accents in two BBC productions as acts of audiovisual translation (AVT) which are illustrative of a more general problematic of Western representations of non-Western languages and cultures. It argues that the phonological features of speech, which are classified as accents, divide the community of native speakers into different social groups and that they create and maintain boundaries between native and non-native speakers. Language discrimination is recognised by the $\mathrm{BBC}$ as a problem in relation to its domestic audience and the Corporation actively attempts to become more inclusive and representative of British society by broadcasting non-standard accents. On the other hand, when representing foreign, and especially post-colonial and non-Western languages and cultures, accent is used to define the boundary between the native English-speaking community and its outside. Accents are used to represent and translate the outside in stereotyping ways that tend towards racialisation and towards actors using generic "Southern African" and "East Asian" accents that bear little resemblance to the actual phonological profile of native speakers of Tswana and Japanese.
\end{abstract}

\section{MOTS-CLÉS/KEYWORDS}

accents, BBC, traduction audiovisuelle, orientalisme, postcolonialisme accents, BBC, audiovisual translation, Orientalism, postcolonialism 


\section{Introduction}

In natural speech situations, accents tell our interlocutors who we are. They identify us as bearers of certain social identities. This is why they are consciously used as a dramaturgical and translational device in radio, television and cinema. The accent enacted can tell us that a character speaking in English is Batswana or Japanese, or that the listener should believe so. But what happens when the characterisation is unrecognisable to a Batswana or Japanese person and s/he feels that his/her identity has been misrecognised? Does it happen more to some languages than others? And why does it happen so often? What is going on when an actor imitates a foreign accent? These are some of the questions that motivate the following paper.

This paper seeks to theoretically reflect on the socially constitutive and reflective role of a dominant culture's translation of subordinate cultures through the strategic use of foreign accents voiced by actors in their native language. It does so through a discussion of the use of English pronounced with Tswana and Japanese accents in two recent BBC television and radio productions: No. 1 Ladies' Detective Agency $(2008)^{1}$ and $M e$, Putin and Judo (2009). ${ }^{2}$ Although limited in its empirical scope, the theoretical arguments are generally applicable to other Anglophone and Western audiovisual representations of non-Western cultures. The paper does not discuss the reverse phenomenon of foreign accents enacted in non-Western media productions, but it must be noted that this is not uncommon in, for instance, Japanese cinema and television.

It is argued that inequalities of political power and cultural status are systematically reproduced through distinctions based on patterns of speech. This takes place internally within a language community, where accent denotes social and geographical origin, as well as in relations between language communities, where accent also demarcates the boundary between the inside and the outside.

Accents differentiate speakers into different groups. Distinctions between native geographically and socially rooted dialects spoken by insiders and foreign accents can be mobilised for different political purposes. While the $\mathrm{BBC}$ attempts to become more inclusive and representative of British society by broadening the varieties of (mostly British) English heard on the airwaves, the way in which it represents foreign accents tends to affirm and reproduce structures of cultural difference and hierarchy between Britain and the wider world. This is particularly the case for the post-colonial and non-Western world, which tends to be generalised, stereotyped and racialised in a different manner from Western cultures and languages. There is therefore an imbalance and double standard with regard to representations and translations of the West and the Rest.

The dramaturgical use of accents can be considered an aspect of audiovisual translation (AVT) in the broad sense of the transfer of meanings between cultures through language. When actors assume a foreign accent, they are in principle engaging in a similar activity to that of interlingual subtitlers or script translators. They are transmitting their interpretation of factual or fictional content originally expressed, or imagined to be expressed, in another language and culture to speakers of their target language/culture. The conscious and strategic deployment of enacted accents is therefore a form of translation. Unlike subtitling, which transforms speech into writing, and script translation, which transforms a written text into an equiva- 
lent written text in another language, accent is a profoundly oral and auditory act of translation. It shares some general features with other areas of AVT, but there are important differences to bear in mind, which raise analytical and theoretical problems for audiovisual translation studies. Because the communicatively significant information and transformation process is phonological rather than lexical, one cannot analyse deliberately accented speech in audiovisual media discourse in terms of equivalence between target text (TT) and source text (ST). Although the enactment of a foreign accent is an AVT practice, it operates at a different level from that of translated voiceover, dubbing or subtitling. Like other translators, actors voicing accents strive for accuracy, but the target and source are the two cultures and languages themselves rather than words formulated in another language. The ST and target utterances are identical and composed in the same language. The translation consists in the manner in which the words are spoken. The words are secondary to their enunciation and the main semantic content is transferred through the imitation of the way a member of the source language (SL) community will typically pronounce words in the target language (TL).

The way in which enacted accents differ from other textual and AVT practices leads to a different question than the usual one of source-target equivalence. The question becomes whether the representation of the language and culture portrayed is accurate. Does it sound Tswana or Japanese? An important related question is whether the translation is meant to be, or can be, accurate in the same way as ethnographic accounts or other forms of translation. Can the translated cultures recognise themselves in back-translation? The two BBC productions discussed below suggest that the answer is no. The representations of Tswana and Japanese are neither linguistically accurate nor meant to be so because the translations of Botswana and Japan are instrumental to a British/Western self-reflection. The two categories become generalised Southern African and East Asian Others.

As the title of this thematic issue testifies to, the concept of ideology has once again become prominent on the intellectual agenda after the long reign of poststructuralist scepticism regarding its utility. One is, however, reluctant to argue with epistemological confidence that the cases discussed below are necessarily instances of ideology in action or of manipulative intent. This author shares Foucault's reservations about the concept of ideology and prefers to bracket the question:

The notion of ideology appears to me to be difficult to make use of, for three reasons, the first is that, like it or not, it always stands in virtual opposition to something else which is supposed to count as truth. Now I believe that the problem does not consist in drawing the line between that in a discourse which falls under the category of scientificity or truth, and that which comes under some other category but in seeing historically how effects of truth are produced within discourses which in themselves are neither true nor false. The second drawback is that the concept of ideology refers, I think necessarily, to something of the order of a subject. Thirdly, ideology stands in a secondary position relative to something which functions as its infrastructure, as its material, economic determinant, etc. For these three reasons, I think that this is a notion that cannot be used without circumspection. (Foucault 1984: 118) 


\section{Accents, Orientalism and the translation of cultures}

An accent can be defined as "a way of saying words that shows what country, region, or social class someone comes from." 3 In a more technical formulation, accents are "loose bundles of prosodic and segmented features distributed over geographic and/ or social space" (Lippi-Green 1997: 42). For sociological and political reasons, accents are accorded different status and some come to be considered accent-less and established as standards, but all speech is accented in the sense that its phonology conveys information about the speaker's social identity. Accent is a socially significant paralinguistic feature of spoken language, which can partly be reproduced textually in phonetic writing systems and mixed ideographic/phonetic systems such as Japanese, but less easily in purely ideographic systems like Chinese. Its strategic use is therefore mostly confined to audiovisual media. It can be translated by an equivalent accent in the TL in voiceover or dubbing but poses problems for subtitling, as writing tends to be accent-neutral. The recipients of a message spoken in an authentic or assumed accent will mobilise a complex range of extra-linguistic social background meanings to contextualise the message and position themselves in relation to the speaker and the wider system of signification. When hearing an accent, the listener will identify the speaker's geographical and social origin within the language community. Within the boundaries of a language community, such as British or US English, accent overlaps with geographically and socially specific dialects and marks the speaker as a native speaker with a certain geographical or social origin. Although both normal speakers in natural speech situations and professional actors can, more or less convincingly, consciously imitate the accents of social groups other than their own, an authentic accent is an involuntary manifestation in language of social structures like region, class, ethnicity, generation, gender and first language. As Lippi-Green demonstrated, the evaluation of accents is intrinsically linked with mechanisms of social domination, discrimination and exclusion:

Accent serves as the first point of gate-keeping because we are forbidden, by law and social custom, and perhaps by a prevailing sense of what is morally and ethically right, from using race, ethnicity, homeland or economics more directly. We have no such compunctions about language, however. Thus, accent becomes a litmus test for exclusion, an excuse to turn away, to refuse to recognize the other. (Lippi-Green 1997: 64)

Accent can be thought of as an aspect of the agonistic establishment and maintenance of hegemony within a linguistic and political community where one can conceive of hegemonic and subaltern accents.

Accents may also, as in the case of the BBC programmes discussed here, signal the accented speaker's constructed status as an outsider to the community of native speakers. In the case of dialects, accent is implicated in the creation and maintenance of social distinctions and divisions among native speakers, usually within a state boundary. Being foreign and hence a non-native speaker of a language also means occupying a position outside the political community of the state. The outsider is "beyond the pale of society," in the etymological sense of being outside the symbolic palisades of the state (Dickens 1837/1986: 652). The original meaning of being beyond the pale in medieval and early modern Ireland was to live outside the Englishspeaking fortified areas around Dublin, or in other words to speak Irish rather than English. Except where class and foreignness interact cumulatively, as for instance in 
the case of non-European economic migrants in Western Europe, a non-native accent is not necessarily interpreted as representing the speaker's class position. It speaks of other systematic international and transnational inequalities of nationality, ethnicity and race. Rather than representing and creating relations of domination and subordination between native speakers of different social variants of the same language, the non-native accent signifies that the bearer of the accent is an outsider, masters the language incompletely and is therefore often considered culturally inferior to native speakers.

The use of accents as a communicative device and, in a broad sense of the term, as a translation strategy in the Anglophone media can be conceived of as a discursive practice in the sense of "practices that systematically form the objects of which they speak" (Foucault 2002: 54). Deliberate imitation of the stereotypical phonological profile of non-native speakers constitutes and reproduces both the subject and object cultures and the relationship between them. The phonological variation between a hegemonic native variant and the subaltern "foreign" accent produced by an actor thus comes to serve as a social marker of identity. It will by necessity be the hegemonic culture's interpretation and representation of the subaltern.

Accents are thus linguistic manifestations of social divisions. They divide speakers of a language into groups. Within a language community, the boundaries of which often coincide with those of the political community of modern states, the accent with which people speak their native language signals belonging to a certain geographical region, socio-economic group or generation. When a language is spoken with a non-native accent, it signals non-belonging to native speakers. Speakers are identified as other than the in-group of the language community and their accent serves to demarcate the inside from the outside of that community (Walker 1993).

In the case of relations between the Anglosphere in particular and Western and non-Western cultures and languages in general, one cannot avoid considerations of the historical legacy of colonialism and its attendant Orientalist and racialising discourses, which continue to influence the way both the West and the Rest think about and hence translate each other. For Saï "Orientalism is a style of thought based upon an ontological and epistemological distinction made between 'the Orient' and (most of the time) 'the Occident"' (Saïd 1978: 2). This basic distinction becomes "the starting point for elaborate theories, epics, novels, social descriptions, and political accounts concerning the Orient, its peoples, customs, 'mind,' destiny, and so on" (Saïd 1978: 2-3). Orientalism is a "Western style for dominating, restructuring, and having authority over the Orient" (Saïd 1978: 3).

A key feature of Orientalism is its construction of an essentialised Orient and Occident binary. As Hall wrote in an extension of Saïd's thesis beyond the Orient to the non-Western world as such:

The discourse as a "system of representation" represents the world according to a simple dichotomy - the West/the Rest. That is what makes the discourse of the West and the Rest so destructive - it draws crude and simplistic distinctions and constructs an over-simplified conception of "difference." (Hall 1996: 189)

Far from being a phenomenon associated only with past colonialism, Orientalism has been strengthened by the audiovisual media: 
[...] there has been a reinforcement of the stereotypes by which the Orient is viewed. Television, the films, and all the media's resources have forced information into more and more standardized molds. So far as the Orient is concerned, standardization and cultural stereotyping have intensified the hold of the nineteenth-century academic imaginative demonology of 'the mysterious Orient.' (Saïd 1978: 26)

According to Saïd, electronic mass media reinforce Orientalist stereotypes (Saïd 1981/1997). One might add to Saïd's observation that this is particularly so when the stereotypes are conveyed by means of the enactment of foreign accents by actors. Even if one does not go as far as McLuhan's claim that "the medium is the message" (McLuhan 2003: 7), the fact that the audiovisual media record and transmit spoken rather than written language constitutes a significant difference between audiovisual and textual representations, as recognised by Benjamin: "The characteristics of film lie not only in the way in which human beings present themselves to the recording equipment, but also in the way they represent the environment by means of this equipment" (Benjamin 1936: 21; translated by the author). ${ }^{4}$

The audiovisual media are characterised by what Benjamin (1936) called "technological reproducibility" of the human voice. This makes it possible to represent non-native accents directly to the listener's ears and to create a more immediate sensory experience. The characteristics of the technology itself are an enabling condition for a more direct form of (mis)representation, which arguably has a stronger cognitive impact than the experience of reading. This is both due to the limited ability of text to convey accent and to the psychological effect of having heard it with one's own ears. While this may not be sufficient to sustain a claim that the medium of communication should be accorded analytical priority over the content, there is a difference to consider between the way accents can be represented in audio and video recordings and the restrictions of a purely textual representation. While they may not be the whole message, the nature of audiovisual media technology creates the enabling conditions for the transmission of messages that are qualitatively different from what can be accomplished in writing. Hearing rather than reading creates a more direct experience.

As Saïd and other postcolonial theorists have shown, many of the underlying assumptions of colonialism continue to operate and influence interaction between former colonising and colonised cultures, including the way both sides translate the culture of the other. This includes such non-Western societies as Japan that were not Western colonies but nevertheless are subject to the cultural consequences of European and American global dominance. In the case of Japan, Arisaka notes that "While Japan was never colonized by the West, the effect the West had on Japanese consciousness resembles its effect on a colonized country" (Arisaka 1999: 246-247). Outside postcolonial studies, there is also a growing recognition across a broad spectrum of intellectual opinion that "the empire is back in town" (Cox 2003) and that imperialism is one of the defining political features of the contemporary world (Cox 2003; Johnson 2004; Williams 2004; Hardt and Negri 2000). As such, the historical legacy of colonialism and contemporary imperialism form part of the context in which translation takes place and should be considered, especially in the case of translation between English and non-Western languages and cultures but also between English and European languages (Steffensen 2009).

As in Victorian times when Bismarck is said to have remarked that the supreme geopolitical fact of the modern era is that the Americans speak English, the legacy 
of the British Empire and the global dominance of the United States today mean that contemporary imperialism speaks English. English is the most widely spoken and written language in human history, and its role as the main medium of global business, science and culture is still growing. The balance between native and non-native English-speakers has, however, tipped, both globally and domestically in the United States:

English is expanding as a lingua-franca but not as a mother tongue. More than 1 billion people speak English worldwide but only about $330 \mathrm{~m}$ of them as a first language, and this population is not spreading. The future of English is in the hands of countries outside the core Anglophone group.

(The Economist 2010)

If, as Marx famously stated, "the ideas of the ruling class are in every epoch the ruling ideas" (Marx 1845-1846), then one might say that the ruling language of today is English as spoken by the elites of the Anglosphere, i.e. primarily mainstream US English and British Received Pronunciation. Within English-speaking communities as well as in relations between Anglophone and non-Anglophone communities, certain forms of the spoken language are hegemonic while others are subaltern.

The strategic deployment of accent in audiovisual media is not translation in the narrow sense of transferring the meaning of a SL text into an equivalent TL text. What it communicates is not so much the meaning of the text itself as socially contextual meanings of an evaluative nature, such as the director's prejudice about speakers of the language and culture represented. Accents can be seen as a form of translation in the broader sense of transmitting meanings between cultures through the medium of language. But unlike Bhabha's (1994: 10-11) imprecise notion of cultural translation, which is more concerned with migration and cultural identity than with linguistic transformation, the conscious and strategic use of non-native accents in the audiovisual media is a linguistic practice and should hence be seen as an aspect of the translation of culture. The translation does not refer narrowly to linguistic matter but to the ideas about self and other embodied in language and is thus one way in which a culture translates another through language. As will be seen in more detail below, in many cases when the translation process is between the West and the Rest, discourse tends towards racialisation of the other.

\section{The BBC's struggle against "BBC English"}

The Cambridge Advanced Learner's Dictionary (2008) defines BBC English as "the standard way in which middle-class speakers of southern British English pronounce words." The Macmillan Dictionary calls it "the standard pronunciation of British English" and adds that "At one time, almost everyone in BBC television and radio programmes used this form of pronunciation, but this is no longer true." It is synonymous with Received Pronunciation and Oxford English and an emblem of class position and education and, to some extent, regional origins in southern England. The pioneer of phonetics, Daniel Jones, stated in his classic English Pronouncing Dictionary that Received Pronunciation is "most usually heard in everyday speech in the families of Southern English persons whose men-folk [had] been educated at the great public boarding-schools" (Jones 1917, cited by Crowley 2003: 143). In the early decades of British broadcasting, the $\mathrm{BBC}$ saw part of its mission as being the 
propagation of a standardised version of spoken English, which tended to be that of the southern, male, educated elite. Over its history, the BBC has become more pluralistic in the range of regional, ethnic and class accents broadcast. It has also come to see the organisation's political role, as reflected in its staffing and output, as one of social inclusion and representation and less as education and cultural leadership.

As George Bernard Shaw's Pygmalion from 1916 attests, the link between language and social disadvantage in Britain has long been recognised and debated. As Shaw phrased it:

It is impossible for an Englishman to open his mouth without making some other Englishman hate or despise him. German and Spanish are accessible to foreigners: English is not accessible even to Englishmen. The reformer England needs today is an energetic phonetic enthusiast: that is why I have made such a one the hero of a popular play. (Shaw 1916: I)

For Shaw, the solution was not the pluralistic one of elevating the subaltern dialects and making working class speech acceptable. As he concludes the introduction to Pygmalion:

Finally, and for the encouragement of people troubled with accents that cut them off from all high employment, I may add that the change wrought by Professor Higgins in the flower girl is neither impossible nor uncommon. The modern concierge's daughter who fulfils her ambition by playing the Queen of Spain in Ruy Blas at the Théâtre Français is only one of many thousands of men and women who have sloughed off their native dialects and acquired a new tongue. But the thing has to be done scientifically, or the last state of the aspirant may be worse than the first. An honest and natural slum dialect is more tolerable than the attempt of a phonetically untaught person to imitate the vulgar dialect of the golf club; and I am sorry to say that in spite of the efforts of our Academy of Dramatic Art, there is still too much sham golfing English on our stage, and too little of the noble English of Forbes Robertson. (Shaw 1916: III)

Rather than pluralising discourse by removing the stigma attached to class dialect, the Fabian socialist hoped to eradicate stigmatising accents altogether and through scientific methods to elevate the masses to the supposedly higher standard of hegemonic elite speech. Shaw's elitist and prescriptive position is a variant of what Wiley and Lukes refer to as a "standard English ideology" where: "Once standards for expected linguistic behaviour have been imposed, privileged varieties of language become a kind of social capital facilitating access to education, good grades, competitive test scores, employment, public office and economic advantages" (Wiley and Lukes 1996: 515).

The "standard English ideology" held by Shaw and most of the British elite in the early $20^{\text {th }}$ century found its expression in the ideal of BBC English as a desirable standard for the listening public to emulate.

However, in recent years the relative absence of regional accents in British broadcasting has become an object of public debate, and today the approach is the opposite of Shaw's. Rather than prescribing and attempting to impose the economic and cultural elite's dialect on British society, the BBC today aspires to reflect the linguistic diversity of contemporary Britain both in the composition of its workforce and in its linguistic output. In 2007, the chairman of the BBC Trust, the Corporation's governing body, admitted that the BBC was widely perceived to be too "Londoncentric." Some months later, the director-general called for "an increase in the 
number of regional accents heard on the corporation's television and radio programmes" (Martin 2008). ${ }^{8}$ There are also diversity and equality policies in place to ensure that the corporation reflects the composition of British society in a more balanced manner. In its own words, "the BBC is committed to reflecting the diversity of the UK audience in its workforce, as well as in its output on TV, on radio and online" (BBC 2010) $)^{9}$ and to "rethinking its relationship with the whole of the UK" (Bennett 2010: 3). ${ }^{10}$

The BBC's diversity and equality policies cover disability, gender and race, but not language. Although dialect/accent is not explicitly mentioned in the Corporation's written policies, there is a growing recognition that the form of language-based discrimination Lippi-Green (1997) termed "dialectism" exists and is politically undesirable. Measures are therefore taken to ensure that less classical BBC English is heard on the airwaves and to get "more non-metropolitan broadcasters - and accents - on to the air" (Thompson 2008, cited by Martin 2008, see note 7). In the words of the BBC Director of Vision, Jana Bennett, this is to be achieved by decentralising the organisation and "harnessing the best talent - wherever it comes from and whatever accent it speaks with" (Bennett 2010: 3, see note 10). In the same speech, Bennett continued: "If the BBC is moving towards being a more inclusive broadcaster then we must pay close attention to the issue of geographic portrayal alongside our other important commitments to diversity of all kinds" (Bennett 2010: 10, see note 10).

Although its audience is global, the BBC's diversity and equality policies only apply to Britain because it is "a public service broadcaster funded by a licence fee paid by all sections of UK society" (see note 9). The licence fee is a form of taxation, and the reasoning goes that it creates a right of representation for viewers and listeners and imposes corresponding obligations on the public service broadcaster. It seems that, at least as far as British society is concerned, the BBC is making efforts to overcome the elitism of its roots as an institution that was, in Lord Reith's words, to "inform, educate and entertain" the masses. ${ }^{11}$ It now sees its mission less in terms of cultural leadership and as being to represent society to itself, including its regional and class linguistic diversity.

Inside the British English-speaking and licence fee-paying community, efforts are therefore made to represent the regions by broadening the range of accents broadcast. The main thrust of the efforts to ensure representation of the linguistic diversity of the inside is directed at reflecting the composition of society in the workforce and programming. The way in which the $\mathrm{BBC}$ hopes to achieve this is by delivering "distinctive voices with an authentic sense of place" (Bennett 2010: 11, see note 10). This means a move to broaden BBC English to include previously marginalised British English accents and thus subaltern social groups.

\section{4. "African" and "Asian" accents on BBC television and radio}

The situation with respect to the outside and the manner in which foreign accents are deployed in radio and television programming seems to be quite different from the attention paid to "geographic portrayal" and "authentic sense of place" within the UK. To the extent that accents from outside the British Isles are portrayed, this is seen as subordinate to the goal of including and representing British minorities. As the Chairman of the BBC Trust proudly proclaimed about the televised version 
of the Rhodesia-born Scottish author Alexander McCall Smith's popular novel series about the No. 1 Ladies' Detective Agency:

\begin{abstract}
There was an outstanding example on BBC One recently in the Number 1 Ladies Detective Agency, a wonderfully warm-hearted piece, set in Botswana, demonstrating all the hallmarks of high quality: good writing, great acting, strong production-values and so on. Nearly 7 million people watched - well above the average for the Sunday night slot. And they loved what they saw - the appreciation index was significantly higher than the average for drama. But what was really interesting was that it drew a large black audience - much higher than the average for BBC One. So it is possible to bring diverse audiences together to share a common $\mathrm{BBC}$ experience - if the $\mathrm{BBC}$ is prepared to take the necessary risks - in this case showcasing at primetime on the flagship channel an entirely black cast with Botswanan accents in an African setting. (Lyons 2008) $)^{12}$
\end{abstract}

One measure of the success of this production set in Botswana and directed by the late Anthony Minghella in 2008 was "that it drew a large black audience" (Lyons 2008, see note 11). The British population of African and Caribbean descent are ascribed a common identity as black, i.e. a racial category that brings together a multitude of culturally and linguistically distinct groups. The enormous range of cultural and linguistic differences from Somalia to Belize and the experience of populations of African descent around the world is subsumed under an all-encompassing notion of blackness. The purpose of showcasing "an entirely black cast with Botswanan accents" and telling a story set in Botswana is to "bring diverse audiences together" in the UK (Lyons 2008, see note 12). In other words, the cultural and linguistic specificity of Botswana matters very little. What matters is that the BBC was "prepared to take the necessary risks" in order to further the integration of British society by showing black actors "at primetime on the flagship channel" (Lyons 2008, see note 11). Whether those actors convey an accurate picture of the way English is spoken in Botswana is secondary.

It is also interesting to note that of the "entirely black cast with Botswanan accents" (Lyons 2008, see note 12) listed on the programme's website, not one is from Botswana. There are two Americans (Jill Scott and Anika Noni Rose), three Britons, one of whom grew up in Tanzania and Zimbabwe (Colin Salmon, Paterson Joseph and Lucian Msamati), and one South African (Desmond Dube). I am not in a position to judge how successful these mostly British and American actors were at reproducing a Tswana-accented English, but those in a better position to judge have not been impressed. Serite writing in the Gaborone Sunday Standard found the effort extremely unconvincing:

Despite being produced entirely in Botswana, it is worrying that certain words have been pronounced differently from local usage. One critic had this to say about this whole assault on pronunciation of some words, "For instance, in Setswana the common address of a man as "Rra" is pronounced "Ra." Also, the Setswana name Mmapula is pronounced in the series with emphasis on the short "a," rather than on the long "u" which most Batswana would use." Whoever was hired as the language / accent / dialect coach, or whatever they are called in the movie industry, should not have been paid a single Thebe. The actors' accent is nowhere near Botswana. The two lead characters, being Mma Ramotswe and her secretary, Mma Makutsi, played by Anika Noni Rose, do not sound anything like Batswana. 
I feel sorry for Jill Scott for all her precious time which was wasted being coached to speak like some Nigerian lady while all she wanted was to learn to speak like a Motswana. (Serite 2010) $)^{13}$

What sounded like a Nigerian accent to a Batswana journalist was, it turns out, the outcome of British and US actors being taught to speak with a Tswana accent by Zimbabweans. According to the female lead Jill Scott herself, in an interview with Morales:

We had studied with dialect coaches an hour a day for two months by phone. You don't hear it all the time and so that changes things. You don't see the clothing and how people behave until you get there. Once there, we had to revamp our characters and the dialect as well. We learned the wrong dialect. They were teaching us a Zimbabwe accent. (Morales 2009) $)^{14}$

The casting and dialect coaching in particular and the general circumstances surrounding the production of the series reflect inequalities of power between the West and Africa as well as regionally within Southern Africa. A commentator in Botswana, Lawrence Ookeditse, wrote:

The perception that Botswana is a province of South Africa is not likely to be debunked any time soon after the release of the well acclaimed No.1 Ladies Detective Agency movie series - better known as Mma Ramotswe. For some film reviewers and locals, the fact that the actors are mostly South African is a cause of concern. [...] Botswana did not have much leverage in the cast of the film and if not for government intervention, the film would have been shot in South Africa. The government offered the filmmakers $\$ 5$ million - enough to offset the costs of importing equipment and crew from South Africa. This ought to have been a great bargaining chip were it not for the tendencies of not only us as Batswana but Africans to constantly under-sell ourselves. $(\text { Ookeditse 2010) })^{15}$

The government of Botswana's contribution of $\$ 5$ million amounts to $12.5 \%$ of the estimated $\$ 40,000,000$ production costs. ${ }^{16}$ But as the comment by Ookeditse and public opinion in Botswana show, there is a perception that very few benefits trickled down to the country and its film industry. Botswana had to pay for the film not to be produced in South Africa and received a disappointingly low return on the investment.

It would seem that to play Batswana on screen, what matters is pigmentation and the ability of English-speaking actors from the globally hegemonic West or regionally hegemonic South Africa to imitate a "Botswanan accent." To the extent that Africa and Botswana matter to the story, it is as a device for including British and US minority audiences. It truly seems that "the subaltern cannot speak" (Spivak 1994: 104) and illustrates Hall's point that the West/Rest discourse oversimplifies complexities of difference (Hall 1996). In spite of the pluralist liberal and anti-racist intentions in Lyons' speech quoted above, the order of discourse which both the speech and the television programme are part of tends to racialise the relationship between the BBC and its ethnic minority viewers. Skin colour becomes "the criterion by which men are judged, irrespective of their social or educational attainments" (Burns 1948: 16, cited by Fanon 1986: 118). In the context of this programme, skin colour seems to matter more than accurate representation. Racialising discourse gives meaning to the particular biological fact of skin colour and assigns heterogeneous groups and individuals to a racial category while pushing otherwise relevant linguistic and 
cultural factors to the background. One therefore has to agree with West that "race matters" (West 1994) in this case as in the next BBC programme to be discussed.

At 11:00 GMT on Friday $9^{\text {th }}$ January 2009, BBC Radio 4 broadcast the programme Me, Putin and Judo. ${ }^{17}$ It was broadcast again some three weeks later on BBC Radio Wales on Saturday $31^{\text {st }}$ January 2009. Me, Putin and Judo is a less high-profile BBC production, and like No. 1 Ladies' Detective Agency it relied on the enactment of a non-Western accent by a voiceover actor. Unlike No. 1 Ladies' Detective Agency, this programme has not received much public attention, but like the television series its use of accent contains insights into the ways in which the BBC and British and Western culture relate to and think about the Rest and use translation to maintain cultural identity and difference. The programme is described by the $\mathrm{BBC}$ as follows:

Former world judo champion Neil Adams visits Russia on a quest to meet fellow judo expert and Russian prime minister Vladamir [sic.] Putin, hoping to gain some insight into how judo has influenced his character. He speaks to Putin's childhood friend, the Duma member Vasily Shestakov, who co-wrote a book with Putin on the philosophy of judo. Neil also meets Putin's judo coach Anatoly Rakhlin and discovers how the Russia [sic.] are preparing for the next Olympics, especially now that judo has become so popular in the country as a result of Putin's example. (BBC 2011, see note 17)

Some sections of the programme were voiced in "foreign-accented English" to represent a stereotyped Orient. A presumably native English-speaking voiceover actor's reading of translated text in an assumed "Japanese" accent, which incidentally sounded more Chinese than Japanese, was a central feature of the programme. The fact that an originally Japanese text translated into English was read in a generic "East Asian" accent by a presumably native English-speaking actor is interesting for students of AVT on many levels. One obvious level, which we shall not concern ourselves with here, is the translation of the Japanese text into English. At another level, the choice of reading the text in an unconvincing Japanese accent is an act of translation in the sense of carrying across from one culture to another. The message carried across is not so much in the words spoken as in the manner of speaking them, in the accent.

The broadcast featured excerpts from the writings of Kano Jigoro, the founder of the martial art judo. As the programme makes clear, and as most people are aware, judo originated in Japan. What is interesting and revealing is that these excerpts were read in a distinctly Chinese accent. Any Japanese-speaker and probably many frequent business travellers to East Asia with no particular linguistic expertise would be able to tell that the phonological patterns reproduced were not characteristically Japanese.

As with Southern Africa in the case discussed above, the impression one gets is that East Asians are all the same to Radio 4 and that it is therefore not necessary to make distinctions that are otherwise made when representing Westerners or people from the former British Empire, especially those from the settler colonies. It is difficult to imagine that French, Spanish, Russian and German accents would be lumped together as a generic "European accent," although these languages are closer relatives than Japanese and Chinese. However, East Asians are treated differently and no account is taken of the significant differences between spoken Chinese and Japanese, which belong to fundamentally dissimilar language groups. In BBC Orientalist discourse, East Asians are treated as collectively different and internally undifferentiated. On the other hand, when it comes to the English language, finer distinctions 
are made between its many spoken variants in Radio 4 broadcasts and one regularly hears US, Canadian, Australian, South Asian, Caribbean and many varieties of regional accents from the British Isles.

The fact that careful distinctions are made between European languages, with English being treated far more sensitively than others, suggests that there is an implicit hierarchy of languages and cultures and ethnocentric double standard in the way the BBC represents them. In Kachru's (1997) scheme, the English language can globally be categorised into three concentric circles: an inner circle, an outer circle and an expanding circle. The inner circle is the Anglosphere where English is spoken as a native language. The outer circle is made up of postcolonial countries where English functions as a de jure official language or de facto language of public life and is widely and fluently spoken by a large number of non-native speakers. The expanding circle is the rest of the world where, to different degrees, English is widely taught as the primary foreign language but does not have official status. This spatial metaphor of horizontal centre and periphery is at the same time a vertical hierarchy of higher and lower levels of cultural-linguistic competence and valuation by the dominant language and culture at the top.

Great care is taken to accurately portray nuances of pronunciation within the language at the top of the hierarchy - English. The greater the cultural distance is from Britain, the less attention is paid to accurate representation of the language. In this hierarchy, languages and peoples perceived to be geographically and culturally distant and relatively unimportant, like Chinese and Japanese, are lumped together on seemingly racial grounds with no regard for the very real linguistic differences that exist.

There are over 500,000 people in the UK of East Asian descent. Census figures exclude those who identify themselves as partially Chinese, but the self-declared ethnic Chinese population in 2006 was over 426,000. This makes the Chinese "the smallest of the main ethnic groups identified in the 2001 Census (Dobbs, Green et al. 2006: 35). An estimated 63,017 Japanese nationals resided in the United Kingdom in $2008 .{ }^{18}$ The number of citizens of the Republic of Korea resident in the UK was 45,295 in $2009 .{ }^{19}$ Figures for the Japanese and Korean population are only for officially registered resident Japanese and Korean citizens. This therefore leaves out several thousand unregistered citizens, British and EU citizens of Japanese and Korean descent, and ethnic Japanese and Koreans with, for example, Canadian, US or Brazilian citizenship. The BBC's treatment of all East Asians as an undifferentiated Oriental mass therefore seems at odds with the corporation's own policy on representing the ethnic diversity of the UK, which states that:

In a devolved, multi-ethnic and multi-faith $\mathrm{UK}$, the role of the $\mathrm{BBC}$ in representing the different nations, regions and communities to each other and to themselves is indispensable. [...] The $\mathrm{BBC}$ has a duty to ensure that its investment in production plays a crucial part in fostering and developing talent across the UK as well as ensuring that all parts of the UK, and all communities within the UK, are represented both in the production process and on screen. (BBC 2005: 97) ${ }^{20}$

The problem in the broadcast was perhaps not so much one of non-representation as of misrepresentation by proxy or what Taylor (1997) terms misrecognition. This is politically problematic for an institution and political culture that subscribe to multiculturalism because: 
A person or a group of people can suffer real damage, real distortion, if the people or society around them mirror back a demeaning or contemptible picture of themselves. Nonrecognition or misrecognition can inflict harm, can be a form of oppression, imprisoning someone in a false, distorted, and reduced mode of being. (Taylor 1997: 98)

A generic actors' Chinese is neither an accurate nor appropriate way to portray a Japanese historical figure. It is a form of misrecognition, which inflicts harm on all East Asians by reducing the differences between Japanese and Chinese, and by extension Korean. As in the case of Botswana discussed above, East Asians are treated as a putatively culturally homogeneous racial category.

The use of non-English accents serves to distance the listener from what is being read and marks it off as alien and often as something not to be taken seriously. Foreign accents in comedy productions clearly serve the purpose of affirming British superiority over Germans, Italians, Spaniards or whoever else is made fun of. Even if Kano's words had been read by a Japanese actor with a genuine accent, the communicative effect would have been similar to that achieved in comedy. The person and the culture he represents would still have come across as exotic and the passages read out would be marked off as something alien and inferior to the authoritative native English voice of the presenter.

Reading quotes from, for instance, Kant, Marx or Hegel in a theatrical Spanish, Greek, Arabic, French or any other generically "Western" non-German accent would be inconceivable unless the purpose was comedic. In fact, broadcasters are highly unlikely to use a German accent when quoting Hegel or a Greek one when quoting Aristotle. Figures from the European canon are appropriated as integral parts of British cultural heritage and therefore represented without accents. This indicates that thinkers from the European tradition are treated more seriously and that nonWestern thinkers are almost parodied. There may be good grounds for not considering Kano a thinker of the same stature as Hegel or Aristotle, but the disrespect shown is not to the man's intellect but to his ethnicity. As the programme was seen through the eyes of a follower of Kano, there can be no question that there was an intention to put him down as a thinker. But putting a Chinese accent in his mouth is a far stronger statement of misrecognition than examining his ideas and concluding that he was a lesser thinker than Hegel or Aristotle.

\section{Concluding remarks}

The above discussion has shown how accents in spoken language constitute and reflect social differentiation. Within a community of native speakers, accents identify speakers as belonging to specific geographical areas and social groups. Accent is also what differentiates native from non-native speakers, thereby signifying another dimension of inclusion and exclusion - the boundaries between the inside and outside of cultural/linguistic communities, which often coincide with the political boundaries of states. Both internally within language communities and in relations between them, accented patterns of speech constitute and reflect wider social patterns of political domination and subordination and the relationships between hegemonic and subaltern social groups, such as ethnic majorities and minorities, elites and masses and imperial centres and peripheries. In the case of translations between the West and the Rest, the relationship is played out against the inescapable historical 
background of colonialism and its contemporary cultural legacy. This is regardless of whether the non-Western culture was formally colonised or not. The cultural consequences of Western domination are similar for both the colonised and noncolonised non-West.

The transmission of spoken words in audiovisual media will necessarily be accented and thus interpreted by the recipient as representing the speech patterns of the particular hegemonic or subaltern group to which the speaker belongs. There is, however, a difference in whether speech transmitted through audiovisual media is the speaker's authentic accent or an enactment by an outsider. In the former case, as in the BBC's broadening of the range of accents heard on television and radio, accent functions as a mechanism of social inclusion where the subaltern is given voice and cultural-linguistic hegemony is modified. When, on the other hand, inauthentic accents are voiced by actors playing the role of non-native speakers, socio-cultural and linguistic boundaries and hierarchies are maintained and reinforced. Accent can thus perform quite different political functions depending on whether it represents the authentic voice of a social or geographical group from the inside of the language community or whether it is an enactment of the in-group's stereotype of the speech patterns of outsiders. Whether accents are deployed transformatively or conservatively, internally or externally, a linguistic transfer of meaning takes place and it should therefore be seen as an act of translation. Like all other translations it takes place in a specific social and historical context.

The relevant social and historical context for the two BBC programmes discussed is the unequal encounter between British/Western culture and generalised constructs of Africa and Asia. The historical legacy of colonialism has contemporary cultural consequences, which manifest themselves in the social construction of identity and alterity in Orientalist and the West/the Rest discourses. As the above discussion has shown for Botswana and Japan, the subaltern, non-Western Other is represented through the linguistic transvestism of Anglophone actors unconvincingly attempting to reproduce typical Tswana and Japanese-accented English. In both cases, the accent reproduced is generic to the supranational regions of Southern Africa and East Asia and bears little resemblance to the actual phonological patterns when native Tswana and Japanese-speakers speak English. The subaltern is represented by generalised "Southern African" and "East Asian" stereotyped accents modelled on the speech patterns of groups other than the ones portrayed. This results in what Taylor (1997) has termed misrecognition of Batswana and Japanese identity. As can be seen in some of the local reactions to No. 1 Ladies' Detective Agency, there is a perception that a distorted view of Botswana has been produced and that the country's claims to an identity as separate from South Africa had been denied. While Me, Putin and Judo has not provoked any known reactions in the Japanese public sphere, being represented by a Chinese accent is equally diminishing to Japanese subjectivity and objectionable to both Japanese and Chinese people.

The two programmes discussed are testimony to the enduring power of Eurocentric, Orientalist and racialising discourse in the encounter between postcolonial Britain and the world. In spite of the explicitly anti-racist intention to reach out to ethnic minorities expressed in Lyons's (2008, see note 12) remarks about No. 1 Ladies' Detective Agency, the way accents were used to translate Botswana and Japan in the two programmes revealed an underlying pattern of classification in terms of 
essentialised racial categories. In its claims about a "black audience" and "an entirely black cast," Lyons's speech also imposed a racialised uniformity on the diversity of people who are "in the final analysis" of African descent (Lyons 2008, see note 12). According to this logic, migrants and British-born people of a multitude of backgrounds ultimately traceable to Africa are essentially the same by virtue of their skin colour. Racialising discourse also makes it entirely uncontroversial to cast British and American actors to portray African characters as long as they have a certain racial profile. When a Zimbabwean accent can stand in for Tswana and a Chinese accent for Japanese as a matter of course, this shows that the languages and ethnicities represented are grouped together along racial lines. These generalisations stand in contrast to the way distinctions are made between different native varieties of English and between European languages. It is difficult to imagine that a Scottish character would be played as a generic "white" voice by means of an enactment modelled on Finnish, to take a hypothetical but analogous example. Unlike ethnic minorities and non-Western peoples, the majority population of Britain and the West are not primarily seen as belonging to racial categories.

The thinking that informs the programmes is the same as that of Glockmann in the 1920s: "They all look alike and they are all called something like Yokohama or Nagasaki" (Yusa 1998: 57). What is lurking in the background is a militant yet selfdoubting Eurocentrism like that of the introduction to Weber's (1905) The Protestant Ethic and the Spirit of Capitalism. The Eurocentrism we can observe today some hundred years after Weber is relatively autonomous from economic forces. One is therefore reluctant to classify it as ideological in the Marxian sense of a reflection of the economic base. China, Japan and the rest of Asia may be thought of as marginal and therefore represented in the Western media as trivial or ridiculous, but this is because ideas are not mechanistically determined by material realities. Asia has an industrial, financial, demographic and military presence in the world to be reckoned with, but Western representations of self and other continue to be relatively unaffected by this. In spite of long and sustained reflection by both Western and nonWestern thinkers, old Eurocentric habits of thought are resilient. So, as Erich Maria Remarque (1929) put it, Im Westen nichts Neues. Decolonisation, hegemonic decline, the rise of East Asia and India, multiculturalism and other real-world developments have not fundamentally affected an Orientalist and racialising discourse with colonial origins. All is quiet on the Western front.

\section{NOTES}

1. No. 1 Ladies' Detective Agency (2008-2009): Directed by Anthony Minghella. United Kingdom/ United States. Visited on 30 June 2012, <http://www.bbc.co.uk/programmes/b00gdz17>.

2. Me, Putin and Judo (2009): Directed by Neil Adams. United Kingdom.

3. Macmillan English Dictionary for Advanced Learners: UK Edition (2002): Entry Accent. Michael Rundell and Gwyneth Fox, eds. Oxford: Macmillan.

4. "Seine Charakteristika hat der Film nicht nur in der Art, wie der Mensch sich der Aufnahmeapparatur, sondern wie er mit deren Hilfe die Umwelt sich darstellt." (Benjamin 1936: 21)

5. The Economist (2010): English as She Was Spoke: The Days of English as the World's Second Language May (Slowly) Be Ending. Visited on 29 September 2011, <http://www.economist.com/ node/17730434?story_id=17730434>.

6. Cambridge Advanced Learner's Dictionary (2008): Entry BBC English. Visited on 14 January 2011, $<$ http://dictionary.cambridge.org/dictionary/british/bbc-english $>$. 
7. Macmillan English Dictionary for Advanced Learners: UK Edition (2002): Entry BBC English. Michael Rundell and Gwyneth Fox, eds. Oxford: Macmillan.

8. Martin, Nicole (17 January 2008): BBC Chief Calls for more Regional Accents. Daily Telegraph. Visited on 29 September 2011, <http://www.telegraph.co.uk/news/uknews/1575790/BBC-chiefcalls-for-more-regional-accents.html>.

9. BBC (2010): Equal Opportunities and Diversity at the BBC. Visited on 29 September 2011, <httpp:// www.bbc.co.uk/aboutthebbc/policies/diversity.shtml>.

10. Bennett, Jana (26 July 2010): Putting Programmes on the Map: Speech Given to Cardiff \& Co. BBC. Press Office. Visited on 30 June 2012, <http://www.bbc.co.uk/pressoffice/speeches/stories/ bennett_cardiff.shtml>.

11. BBC (2010): BBC Mission and Values. Visited on 29 September 2011, <htpp://www.bbc.co.uk/ aboutthebbc/purpose>.

12. Lyons, Michael (14 May 2008): The BBC, the Licence Fee and the Future of UK PSB. Speech to the Royal Society of Arts, London. Visited on 30 June 2012, $<$ http://www.bbc.co.uk/bbctrust/news/speeches/2008/ml_rsa.html >.

13. Serite, Sonny O. (21 January 2010): Mma Ramotswe TV series: A big yawn. Sunday Standard. Visited on 29 September 2011, <http://www.sundaystandard.info/print_article.php?NewsID=6752>.

14. Morales, Wilson (2009): Exclusive Interview: Jill Scott Talks 'The No. 1 Ladies' Detective Agency. Black Voices, 24 March. Visited on 29 September 2011, <htpp://www.bvonmovies.com/2009/03/24/ exclusive-interview-jill-scott-talks-the-no-1-ladies-detecti $>$.

15. Oокeditse, Lawrence (22 January 2010): Mma Ramotswe movie buttresses South African dominance. Mmegionline. 27(11). Visited on 29 September 2011, <http://www.mmegi.bw/index.php?sid=1\&aid=40\&dir=2010/January/Friday22>.

16. Wines, Michael (26 September 2007): Seduced by Botswana: Minghella brings 'No. 1 Ladies' Detective Agency' to the screen. New York Times. 26. Visited on 29 September 2012, <http://www. nytimes.com/2007/09/26/arts/26iht-ladies.1.7639361.html?pagewanted=all\&_r=0>.

17. BBC (2011): Me, Putin and Judo. Visited on 29 September 2011, <htpp://www.bbc.co.uk/programmes/b00gdz17>.

18. MOFA (2011): Japan-UK relations. Ministry of Foreign Affairs of Japan. Visited on 29 September 2011, <http://www.mofa.go.jp/region/europe/uk/index.html>.

19. MOFAT (2010): Current Status of Overseas Compatriots. Ministry of Foreign Affairs and Trade of the Republic of Korea. Visited on 29 September 2011,

$<$ http://www.mofat.go.kr/consul/overseascitizen/compatriotcondition/index6.jsp?TabMenu=Tab Menu6>.

20. BBC (2005): Review of the BBC's Royal Charter: BBC Response to A Strong BBC, Independent of Government. London: BBC. Visited on 30 June 2012, <http://downloads.bbc.co.uk/aboutthebbc/ insidethebbc/howwework/reports/pdf/green_paper_response.pdf $>$.

\section{REFERENCES}

Arisaka, Yoko (1999): Beyond 'East and West': Nishida's universalism and postcolonial critique.” In: Fred R. Dallmayr, ed. Border Crossings: Toward a Comparative Political Theory. Lanham: Lexington Books, 227-251.

Внавна, Homi K. (1994): The Location of Culture. London: Routledge.

BENJAMIN, Walter (1936): Das Kunstwerk im Zeitalter seiner technischen Reproduzierbarkeit [The Work of Art in the Age of Mechanical Reproduction]. Visited on 29 September 2011, <http:// www.arteclab.uni-bremen.de/ robben/KunstwerkBenjamin.pdf >.

Burns, Sir Alan (1948): Colour Prejudice. London: Allen \& Unwin.

Cox, Michael (2003): The empire is back in town: or America's imperial temptation - again. Millenium: Journal of International Studies. 32(1):1-27.

Crowley, Tony (2003): Standard English and the Politics of Language. Basingstoke: Palgrave Macmillan.

Dickens, Charles (1837/1986): The Pickwick Papers. Oxford: Oxford University Press.

Dobbs, Joy, Green, Hazel and Zealey, Linda, eds. (2006): Focus on Ethnicity and Religion. London: Office for National Statistics.

FAnon, Frantz (1986): Black Skin, White Masks. London: Pluto. 
Foucault, Michel (1984): The Foucault Reader. New York: Pantheon Books.

Foucault, Michel (2002): The Archaeology of Knowledge. London: Routledge.

HALl, Stuart (1996): The West and the rest: discourse and power. In: Stuart Hall, David Held, Don Hubert, et al., eds. Modernity: An Introduction to Modern Societies. Oxford: Blackwell, 184-228.

Hardt, Michael and Negri, Antonio (2000): Empire. Cambridge: Harvard University Press.

Johnson, Chalmers A. (2004): The Sorrows of Empire: Militarism, Secrecy and the End of the Republic. New York: Metropolitan Books.

KACHRU, Braj (1997): World Englishes 2000: Resources for Research and Teaching. In: Larry E. SMith and Michael L. Forman, eds. World Englishes 2000. Honolulu: University of Hawaii, 209-251.

LippI-Green, Rosina (1997): English with an Accent: Language, Ideology and Discrimination in the United States. New York: Routledge.

Marx, Karl (1845-1846/1932): The German Ideology: Critique of Modern German Philosophy According to Its Representatives Feuerbach, B. Bauer and Stirner, and of German Socialism According to Its Various Prophets. Visited on 29 September 2011, $<$ http://www.marxists.org/archive/marx/works/1845/german-ideology>.

McLuhan, Marshall (2003): Understanding Media: The Extensions of Man. Critical edition by W. Terrence Gordon. Berkeley: Gingko Press.

Remarque, Erich Maria (1929/1929): All Quiet on the Western Front. (Translation of Im Westen nichts Neues by Arthur Whesley-Wheen) New York: Little Brown and Company.

SAÏD, Edward W. (1978): Orientalism. New York: Pantheon.

SAÏD, Edward W. (1981/1997): Covering Islam: How the Media and the Experts Determine how We See the Rest of the World. New York: Vintage Books.

SHAw, George Bernard (1916): Pygmalion. New York: Brentano.

SPIVAK, Gayatri Chakravorty (1994): Can the Subaltern Speak? In: Patrick Williams and Laura Chrisman, eds. Colonial Discourse and Post-Colonial Theory: A Reader. New York: Harvester and Wheatsheaf, 66-111.

Steffensen, Kenn Nakata (2009): Denmark's invisible empire: The politics of translating the Danish constitutional order. In: Brett J. Epstein, ed. Northern Lights: Translation in the Nordic countries. Oxford: Peter Lang.

Taylor, Charles (1997): The politics of recognition. In: Ajay Heble, Donna Palmateer Pennee and J. R. Tim Struthers, eds. New Contexts of Canadian Criticism. Peterborough: Broadway Press, 98-130.

Walker, Rob B. J. (1993): Inside/Outside: International Relations as Political Theory. Cambridge: Cambridge University Press.

Weber, Max (1905): The Protestant Ethic and the Spirit of Capitalism. Visited on 29 September 2011, <http://www.marxists.org/reference/archive/weber/protestant-ethic/index.htm>.

West, Cornel (1994): Race Matters. New York: Vintage Books.

Wiley, Terence and Lukes, Marguerite (1996): English-only and standard English ideologies in the U.S. TESOL Quarterly. 30(3):511-535.

Williams, David (2004): Defending Japan's Pacific War: The Kyoto School Philosophers and Post-White Power. London: Routledge.

YusA, Michiko (1998): Philosophy and Inflation. Miki Kiyoshi in Weimar Germany, 1922-1924. Monumenta Nipponica. 53(1):45-71. 